\title{
PERWUJUDAN SILA KE EMPAT PANCASILA SETELAH PERUBAHAN UNDANG-UNDANG DASAR 1945
}

\author{
Herlambang \\ Fakultas Hukum Universitas Bengkulu \\ J1. WR. Supratman Kandang Limun Kota Bengkulu \\ Herlambang@unib.ac.id
}

\begin{abstract}
The most important topics discussed in community of law is the legal position as the source of all sources of law. The next question is whether automatically any laws either in the form of legislation, customs and court decisions that exist in Indonesia has been based on the values contained in Pancasila. Pancasila as the basic thoughts and as an aspiration of which order state law meant and intended to bring happiness and prosperity, peace and freedom of the peoples of Indonesia. Ideas to implement the values of Pancasila as the source af all sources of law in Indonesia is the constitutional order. This paper discusses in further on the review of the special values of the precepts fourth of Pancasila, namely democracy led by wisdom of wisdom in consultative representation, consisting of characteristic elements of democratic Indonesia; wisdom; deliberation and consensus and representative institutions.
\end{abstract}

Keywords : Pancasila, democracy, Constitution.

\begin{abstract}
Abstrak
Topik yang paling penting dibicarakan dalam komunitas pencinta hukum adalah kedudukan hukum sebagai sumber dari segala sumber hukum. Pertanyaan berikutnya adalah apakah secara otomatis segala produk hukum baik berbentuk peraturan perundang-undangan, kebiasaan maupun putusan pengadilan yang ada di Indonesia telah di dasarkan pada nilai-nilai yang terkandung di dalam Pancasila. Pancasila sebagai pokok-pokok pikiran dan suatu cita-cita hukum diantaranya agar supaya negara dimaksudkan dan ditujukan untuk mewujudkan kebahagiaan dan kesejahteraan, perdamaian dan kemerdekaan dalam masyarakat bangsa Indonesia. Ide dan gagasan untuk mengimplementasikan nilai-nilai yang terkandung Pancasila sebagai sumber dari segala sumber hukum di Indonesia, merupakan perintah konstitusional. Tulisan ini membahas secara lebih jauh tentang penelaahan terhadap nilai-nilai khusus yang terkandung dalam sila keempat dari Pancasila yaitu kerakyatan yang dipimpin oleh hikmah kebjaksanaan dalam permusyawaratan perwakilan, yang terdiri dari unsur-unsur karakteristik kerakyatan Indonesia, hikmat kebijaksanaan, musyawarah dan mufakat dan lembaga perwakilan.
\end{abstract}

\section{Kata Kunci : Pancasila, Demokrasi, Undang-Undang Dasar .}




\section{PENDAHULUAN}

Topik Diskusi tentang Pancasila pada era Reformasi menjadi kurang bergairah jika dibandingkan pada era sebelumnya. Beberapa fenomena unik terjadi diseputar pancasila. Konflik terhadap hari lahirnya Pancasila, 3 Pilar, dan yang terbaru adalah kasus "Zaskia Gotik" yang diangkat sebagai duta Pancasila oleh FPKB. Peristiwa tersebut sudah sepantasnya membuat kita galau, jangan-jangan pada masa yang akan datang tinggal sedikit orang mengenang Pancasila. Dulu orang diingatkan betapa strategisnya Pancasila, karena kedudukannya sebagai Falsafah Bangsa, Dasar negara dan sumber dari segala sumber hukum. Kini setiap upacara bendera, Pancasila dibaca oleh pemimpin upacara dan diikuti oleh seluruh peserta upacara.

Salah satu senjata pamungkas yang digunakan untuk menyerang usaha membumikan pancasila sebagai falsafah bangsa yang menjadi pedoman hidup bangsa Indonesia adalah gerakan tersebut dilakukan dengan metode indoktrinasi, sehingga upaya pemaksaan tersebut berhenti bersama-sama dengan berhentinya orde baru. Salah satu faktor yang mempengaruhi eksistensi pancasila Herlambang, Perwujudan Sila Ke Empat Pancasila Setelah Perubahan Undang-Undang Dasar 1945 pada masa orde baru, pertama, Pancasila sudah terlanjur tercemar karena kebijakan rezim suharto yang politik untuk mempertahankan status quo kekuasaannya ${ }^{1}$. orde baru

Pembicaraan Pancasila sebagai Ideologi negara baru saja diterima oleh seluruh komponen bangsa sehingga seluruh organisasi yang ada di negara indonesia harus berdasarkan pada Pancasila. Pertanyaan selanjutnya adalah apakah seluruh aktivitas organisasi tersebut sudah mencerminkan silasila Pancasila, sebagai contoh apakah performance "Organisasi Pemuda Pancasila" dapat mewakli penampakan Pancasila Itu sendiri.

Topik yang paling penting dibicarakan dalam komunitas pencinta hukum adalah kedudukan hukum sebagai sumber dari segala sumber hukum. Apakah secara otomatis segala produk hukum baik berbentuk peraturan perundangundangan, kebiasaan maupun putusan pengadilan yang ada di Indonesia telah di dasarkan pada

1 Azyumardi Asra yang dikutip oleh Sadi Isra. Reaktualisasi Pancasila dalam Kehidupan Multikulturalisme. Seminar nasional "Eksistensi Pancasila dalam era Pluralisme". BEM FH Univ, Atmajaya. Yogyakarta. 2 Mei 2009. menjadikan Pancasila sebagai alat 
nilai-nilai yang terkandung di dalam

Pancasila. Pertanyaan ini selalu menggoda untuk dijawab oleh pembelajar hukum. Para pendahulu yang mencoba memberikan kisi-kisi dan menemukan karakteristik bagi hukum pancasila. Mulai sejak Soepomo, M, Yamin dan generasi yang lebih baru seperti Notonagoro, Padmo Wahyono, dan Romli Antasasmita.

Pancasila sebagai pokok-pokok pikiran dan sebagai suatu cita-cita hukum diantaranya agar supaya negara dimaksudkan dan ditujukan untuk mewujudkan kebahagiaan dan kesejahteraan, perdamaian dan kemerdekaan dalam masyarakat bangsa Indonesia. Kemudian lebih jauh agar negara itu didasarkan atas pengakuan ketuhaan yang maha Esa, peri kemanusiaan, kebangsaan, kerakyatan dan keadilan sosial rakyat Indonesia. ${ }^{2}$

Tanpa sila-sila Pancasila, uang akan dipertuhankan, korupsi menjadi budaya kehidupan, kebangsaan (nasionalisme) sebagai keadulatan berbangsa dan bernegara akan diremehkan, dilecehkan, selanjutnya kita tidak merasa risih menjadi jongos

2 Roeslan Abdul Gani, yang dikutip oleh Heri Santoso dkk.Uj koherensi dan korespodensi. Aktualisasi nilai- nilai pancasila dalam produk undang-undang, Pasca Reformasi (Tinjauan Filosofis, sosiologis dan Yuridis.. Prosiding Kongres Pancasila IV: Srategi Pelembagaan NilaiNilai Pncasila. https://books.google.co.id Herlambang, Perwujudan Sila Ke Empat Pancasila Setelah Perubahan Undang-Undang Dasar 1945 globalisasi, dan bukan menjadi tuan di negeri sendiri. ${ }^{3}$

\section{PEMBAHASAN}

A. Implementasi Sila-sila Pancasila dalam Konstitusi negara

Ide dan gagasan untuk mengimplementasikan nilai-nilai yang terkandung Pancasila sebagai sumber dari segala sumber hukum di Indonesia, merupakan perintah konstitusional. Pancasila merupakan sumber nilai dan dan nilai nilai yang terkandung didalamnya dibentuklah norma-norma hukum oleh Negara. ${ }^{4}$ Penjabarkan nilai-nilai yang terkandung di dalam sila-sila Pancasila diberikan di dalam UndangUndang Dasar 1945.

Dalam alinea ke empat
Pembukaan UUD 1945,
termuat unsur- unsur yang
menurut ilmu hukum di
syaratkan bagi adanya suatu
tertib hukum di Indonesia
(rechts orde) atau (legai orde)
yaitu suatu kebulatan dan
keseluruhan peraturan-
peraturan hukum. Dengan di
cantumkanya Pancasila secara
formal didalam pembukaan
UUD 1945, maka Pancasila
memperoleh kedudukan

3 Sri Edi Swasono. Pancasila dan Tanggungjawab Intlektual kita. Seminar nasional Strategi Pembudayaan nilai nilai Pancasila.dalam menguatkan semangat keindonesiaan. Prosiding Kongres Pancasila Ke V Tahun 2013

${ }^{4}$ Ongki Setio Kuncono.Poisi Pancasila sebagai landasan Hukum Di Indoesia. http://www.spocjournal.com/ hukum. diunduh pada hari selasa tanggal 12 April 2016 pukul 16.19 
sebagai norma dasar hukum positif, dengan demikian tata kehidupan benegara tidak hanya bertopang pada asasasas sosial, ekonomi, politik, akan tetapi dalam perpaduanya dengan keseluruhan asas yang melekat padanya yaitu panduan asas- asas kultural. ${ }^{5}$

Undang-undang Dasar 1945 merupakan pokok-pokok pikiran utama para pendiri bangsa tentang bagaimana negara ini diselenggarakan berdasarkan ketentuan hukum atau disebut sebagai negara hukum. Kedudukan Pancasila sebagai dasar Negara tersebut menurut Kaelan, yang dikutip oleh Ongki dapat diperinci sebagai berikut :

1. Pancasila sebagai dasar Negara adalah merupakan sumber dari segala sumber hukum ( sumber tertib hukum) Indonesia. Dengan demikian Pancasila merupakan asas kerokhanoian tertib hukum Indonesia yang dalam Pembukaan UUD 1945 dijelmakan lebih lanjut dalsam Empat Pokok Pikiran.

2. Meliputi suasana kebatinan ( Geistlicbenbintergrund) dari Undang Undang Dasar 1945.

3. Mewujudkan cita-cita hukum bagi hukum dasar Negara ( baik hukum dasar tertulis maupun tidak tertulis )

4. Mengandung norma yang mengharuskan Undang Undang Dasar mengandung isi yang mewajibkan pemerintah dan lain lain penyelenggara Negara ( termasuk para penyelenggara

5 Sri Widayati. Arti Pancasila Sebagai Sumber Hukum. http://www.gexcess.com. Diunduh pada Hari selasa tanggal 12 april 2016 pukul 16.21 partai dan golongan fungsional) memegang teguh cita-cita moral rakyat yang luhur. Hal ini sebagaimana tercantum dalam pokok pikiran keempat yang bunyinya sebagai berikut " .....Negara berdasarkan atas Ketuhanan Yang Maha Esa, menurut dasar kemanusiaan yang adil dan beradab".

5. Merupakan sumber semangat bagi Undang Undang Dasar 1945, bagi penyelenggara Negara, para pelaksana pemerintahan ( juga para penyelenggara partai dan golongan fungsional) $\mathrm{Hal}$ ini dapat dipahami karena semangat adalah penting bagi pelaksanaan dan penyelenggaraan Negara karena masyarakat dan negara Indonesia senantiasa tumbuh dan berkembang seiring dengan perkembangan zaman dan dinamika masyarakat. Dengan semangat yang bersumber pada asas kerokhanian Negara sebagai pandangan hidup bangsa, maka dinamika masyarakat dan Negara akan tetap diliputi dan diarahkan asas kerokhanian Negara. ${ }^{6}$

Nilai-nilai Pancasila bersifat universal, sehingga harus diinternalisasi dalam kehidupan berbangsa dan bernegara, termasuk pembangunan hukum. Dalam kaitannya dengan pembangunan, hukum mempunyai fungsi sebagai pemelihara ketertiban dan keamanan, sarana pembangunan, penegak

${ }^{6}$ Op.Cit Ongki.. Lihat juga Kaelan. Negara Kebangsaan Pancasila. Paradigma. Yogyakarta 2013Hlm 472.

Herlambang, Perwujudan Sila Ke Empat Pancasila Setelah Perubahan Undang-Undang Dasar 1945 
Supremasi Hukum : Jurnal Penelitian Hukum

p-ISSN: 1693-766X ; e-ISSN: 2579-4663, Vol. 26, No. 2, Agustus 2017

keadilan dan pendidikan masyarakat. ${ }^{7}$

Sehingga segala bentuk aktivitas

pengembangan (rechsbeoefening)

hukum nasional harus berdasarkan

nilai -nilai yang termuat dalam

pancasila sebagai norma dasar

Negara. ${ }^{8}$ Negara hukum Pancasila

mengandung lima asas, yaitu :

Pertama, asas Ketuhanan

Yang Maha Esa. Asas ini

tercantum pada

Pembukaan UUD 1945

alinea ke IV, yaitu “...

maka disusunlah

kemerdekaan kebangsaan

Indonesia itu dalam suatu

UUD Indonesia yang

berkedaulatan rakyat

dengan berdasarkan

Ketuhanan Yang Maha

Esa. ${ }^{9} \quad$ Berdasarkan

pernyataan ini, Indonesia

merupakan negara yang

ber-Tuhan, agama

dijalankan dengan cara

yang berkeadaban,

hubungan antar umat

beragama, kegiatan

beribadahnya dan

toleransi harus

berdasarkan pada

7 Ali Taher Parasong. Internalisasi

Pancasila dalam Pembentukan

peraturan Perundang-undangan di

Indonesia. http://fhumj.org diunduh pada hari selasa tanggal 12 April 2016 pukul 1634

8 Dani Pinasang . Falsafah

Pancasila Sebagai Norma Dasar ((grundnorm) dalam rangka pengembanan sistem hukum nasional. Jurnal Unsrat Vol.XX/ No 3/Apri -juni/2012. http://repo.unsrat.ac.id. Diunduh Pada Hari Jum'at tanggal 15 April 016 pukul $11 ; 14$.

9 Op Cit Ali Taher. Lihat Juga Yudi Latif, Negara Paripurna: Historisitas, Rasionalitas, dan Aktualitas Pancasila, Jakarta: Kompas Gramedia, 2011, hlm. 67.

Herlambang, Perwujudan Sila Ke Empat Pancasila Setelah Perubahan Undang-Undang Dasar 1945
Ketuhanan. Kebebasan beragama harus dilaksanakan berdasarkan pada tiga pilar, yaitu freedom (kebebasan), rule tolerance (toleransi).

Kedua, asas perikemanusiaan

universal. Asas ini mengakui dan memperlakukan manusia sesuai dengan harkat dan martabatnya sebagai makhluk Tuhan, juga mengakui persamaan derajat, persamaan hak dan kewajiban asasi manusia tanpa membedabedakan suku, keturunan, agama, ras, warna kulit, kedudukan sosial, dan lainnya. Dalam Pembukaan UUD 1945 merupakan perwujudan dari asas perikemanusiaan dalam hukum positif Indonesia dalam kehidupan sehari-hari hal ini terlihat pada lembagalembaga yang didirikan yang tidak seimbang dalam kehidupan sosial.

Ketiga, asas kebangsaan atau persatuan dalam kebhinekaan, yaitu setiap warga negara mempunyai kedudukan, hak, dan kewajiban yang sama. Asas ini menunjukkan, bahwa bangsa Indonesia bebas untuk menentukan nasibnya sendiri dan berdaulat, sehingga tidak membolehkan adanya campur tangan (intervensi) dari bangsa lain dalam hal mengenai urusan dalam negeri. of law (aturan hukum) dan untuk menampung segala 
Keempat, asas demokrasi permusyawaratan atau kedaulatan rakyat. Penjelmaan dari asas ini dapat dilihat pada persetujuan dari rakyat atas pemerintah itu dapat ditunjukkan bahwa presiden tidak dapat menetapkan suatu peraturan pemerintah, tetapi terlebih dahulu adanya undang-undang artinya tanpa persetujuan rakyat Presiden tidak dapat menetapkan suatu peraturan pemerintah.

Kelima, asas keadilan sosial. Asas ini antara lain diwujudkan dalam pemberian jaminan sosial dan lembaga negara yang bergerak di bidang sosial yang menyelenggarakan masalah-masalah sosial dalam negara. ${ }^{10}$

Pengaturan tentang Majelis permusyawaratan Rakyat di dalam Undang-undang Dasar 1945 seharusnya bersumberkan pada nilainilai yang tekandung di alam sila-sila Pancasila

B. Nilai nilai yang terkandung dalam sila ke empat Pancasila

Pembahasan tentang nilai pada dasarnya merupakan kajian filsafat, khususnya bidang filsafat yang disebut aksiologi. Pertanyaan atau pemikiran kefilsafatan yang cirinya antara lain kritis dan mendalam, di

\section{Ibid}

sini dimulai dengan pertanyaan : apakah hakikat nilai itu? pertanyaan ini menginginkan jawaban yang simultan, general dan abstrak. Jawabannya haruslah bersifat hakiki yaitu sesuatu yang harus ada pada sesuatu dan apabila sesuatu itu tidak ada maka hilanglah makna akan sesuatu tersebut. Hal berarti dalam menjawab pertanyaan apakah hakikat nilai yang terkandung di dalam Pancasila tersebut, maka jawabannya harus mengenai sesuatu yang harus ada pada sila-sila pancasila tersebut, yang menjadi karakteristik yang membedakan dengan niali-nilai lainnya.

Nilai yang dalam bahasa Inggrisnya adalah value biasa diartikan sebagai harga, penghargaan, atau taksiran. Maksudnya adalah harga yang melekat pada sesuatu atau penghargaan terhadap sesuatu. Bambang Daroeso (1986:20) mengemukakan bahwa nilai adalah suatu kualitas atau penghargaan terhadap sesuatu, yang dapat menjadi dasar penentu tingkah laku seseorang. Darji Darmodiharjo (1995: 1) mengatakan bahwa nilai adalah kualitas atau keadaan sesuatu yang bermanfat bagi manusia, baik lahir maupun batin. Sementara itu Widjaja (1985: 155) mengemukakan bahwa menilai berarti menimbang, yaitu kegiatan menghubungkan sesuatu dengan sesuatu yang lain (sebagai standar), untuk selanjutnya mengambil keputusan. Keputusan itu dapat menyatakan : berguna 
atau tidak berguna, benar atau tidak benar, indah atau tidak indah, baik atau tidak baik dan seterusnya. Menurut Fraenkel, sebagaimana dikutip oleh Soenarjati Moehadjir dan Cholisin (1989:25), nilai pada dasarnya disebut sebagai standar penuntun dalam menentukan sesuatu itu baik, indah, berharga atau tidak. ${ }^{11}$

Pancasila merupakan suatu sitem nilai, sudah memenuhi syarat sebagai sebuah sistem, atau dengan kata lain Pancasila bersifat sistematis/sistematik, karena:

1. Pancasila terdiri dari beberapa Sila, yakni Lima Sila

2. Diantara Lima Sila mempunyai hubungan yang sifatnya hirarkis (Sila pertama: Ketuhanan mendasari dan menjiwai sila kemanusiaan, Sila persatuan, Sila kerakyatan dan Sila keadilan

3. Diantara Sila-Sila dalam Pacasila tidak saling bertentangan, bahkan merupakan satu kesatuan yang bersifat komprehesif integralistik, ${ }^{12}$

Pancasila pada hakikatnya adalah sistem nilai (Value) yang merupakan kristalisasi nilai-nilai luhur kebudayaan bangsa Indonesia sepanjang sejarah, dan kebudayaan yang berakar dari unsur-unsur kebudayaan luar yang sesuai

11 Nn. Teori Nilai. staff.uny.ac.id. diunduh Pada hari Rabu Tanggal 13 April 2016. Pukul. 14.22

12 Indri Djanarko. Pancasila sebagai sistem Filsafat. http://indridjanarko.dosen.narotama.ac.i d. Diunduh pada hari selasa Herlambang, Perwujudan Sila Ke Empat Pancasila Setelah Perubahan Undang-Undang Dasar 1945 sehingga secara keseluruhanya terpadu menjadi kebudayaan bangsa Indonesia. ${ }^{13}$

Pancasila sebagai filsafat, memiliki karasteristik sistem filsafat tersendiri yang berbeda dengan filsafat lainnya, di antaranya:

1. Sila-sila Pancasila merupakan satu kesatuan sistim yang bulat dan utuh (sebagai suatu totalitas). Dengan pengertian lain, apabila tidak bulat dan utuh atau satu sila dengan sila lainnya terpisah-pisah, maka itu bukan pancasila.

2. Susunan Pancasila dengan suatu sistim yang bulat dan utuh itu dapat digambarkan sebagai berikut

a. Sila 1, meliputi, mendasari, dan menjiwa: sila 2, 3, 4, dan 5 .

b. Sila 2, diliputi, didasari, dan dijiwai sila $1, \quad$ serta mendasari dan mcnjiwai sila 3,4 , dan 5 .

c. Sila 3, diliputi, didasari, dan dijiwai sila 1,2 , serta mendasari dan menjiwa; sila 4 dan 5. -

d. Sila 4, diliputi, didasari, dan dijiwai sila 1,2 , dan 3 , serta mendasari dan menjiwai sila 5.

e. Sila 5, diliputi, didasari, dan dijiwai sila 1, 2, 3, dan 4 .

f. Pancasila sebagai suatu substansi, artinya unsur asli/permanen/primer

g. Pancasila sebagai suatu yang ada mandiri, yang unsurunsurnya berasal dari dirinya sendiri.

${ }^{13}$ ahmadnasher. Pancasila sebagai
sistem ahmadnasher.staff.gunadarma.ac.id.

diunduh pada hari selasa tanggal 12 April 2016. Pukul 12.40 
h. Pancasila sebagai suatu realitas, artinya ada dalam diri manusia Indonesia dan masyarakatnya, sebagai suatu kenyataan hidup bangsa, yang tumbuh, hidup, dan berkembang dalam kehidupan seharihari. ${ }^{14}$

Secara aksiologis, nilai itu dibagi macamnya menurut kualitas nilainya, yaitu ke dalam nilai baik dan buruk yang dipelajari oleh etika, dan nilai indah dan tidak indah yang dipelajari oleh estetika. Akan tetapi macam-macam nilai kemudian berkembang menjadi beraneka ragam, tergantung pada kategori penggolongannya. ${ }^{15}$

Penelaahan terhadap nilai-nilai yang terkandung dalam sila Keempat dari pancasila yaitu; "Kerakyatan yang dipimpin oleh hikmah kebjaksanaan dalam permusyawaratan perwakilan", harus mengingat satu hal bahwa pembicaraan terhadap sila ke empat, tidak dapat dipisahkan dari keempat sila-sila lainnya di dalam pancasila. Sila kempat pancasila secara harfiah dapat dibaca menjadi, pengurusan rakyat indonesia harus dilakukan sesuai dengan karakteristik Indonesia. Pengurusan hak dan

14 Rowland Bismark Fernando Pasaribu. Pancasila sebagi sistem Filsafat. staff.gunadarma.ac.id. diunduh pada hari Jum'at tanggal 15 April 2016 pukul 11.01 15 ibid kewajiban rakyat indonesia harus dilakukan secara musyawarah mufakat dengan berdasarkan hikmat dan kebijaksanaan. Musyawarah mufakat hanya dapat dilakukan di dalam suatu lembaga perwakilan.

1. Karakteristik kerakyatan Indonesia Sila yang keempat mencerminkahn tata cara dan mekanisme dalam memperjuangkan usaha-usaha kerakyatan. Sila keempat sering dijadikan sistem demokrasi di Indonesia. Demokrasi itu sendiri bukan suatu wujud yang kaku, tetapi sistemnya tidak harus seragam disemua tempat tetapi disesuaikan dengan kondisi sosialkultural bangsa indonesia yang demikian majemuk. ${ }^{16}$ Asas kekeluargaaan adalah suatu bangunan yang unggul dan dapat diterapkan dalam masyarakat modern. Manifestasinya antara lain adalah keinginan untuk selalu mendahulukan musyawarah dan mufakat guna menghindar diktator mayoritas atau tiranim minoritas. ${ }^{17}$ Pembicaraan mengenai kerakyatan indonesia, maka satu hal yang harus tetap diingat adalah bahwa terdapat

\section{Ginanjar Kartasasita.} karakteristidka ns truktur masyarakat indonesia $\mathrm{m}$ odern. disampaikanp ada sarasehan $\mathrm{u}$ ji sahih a tas pokok-pokok pikiran golkar tentang gbhn 1998. Jogyakarta 27 Juni 1997. Hlm 14-15 17 Ibid

Herlambang, Perwujudan Sila Ke Empat Pancasila Setelah Perubahan Undang-Undang Dasar 1945 
satu kenyataan adanya kemajemukan struktur poiotik, ekonomi, soaial dan kultural. ${ }^{18}$

\section{Hikmat kebijaksanaan}

Ciri kedua yang terkandung dalam nilai-nilai pada sila keempat adalah penyelengaraan urusan kerakyatan Indonesia harus dilakukan dangan hikmah kebijaksanaan, bukan kepentingan pratis semata-mata. Prinsip Demokrasi yang pada gilirannya berdasarkan pemikiran dan falsafah serta nilai yang terkandung dalam sila kedua (Kemanusiaan yang Adil dan Beradab).

$$
\text { Prinsip bahwa setiap }
$$

keputusan yang diambil hendaknya dicapai setelah dimusyawarahkan dan dipertimbangkan segala segi dan aspek yang berkaitan dengan masalah yang dibahas secara bijaksana. Jadi secara seimbang dan tidak berat sebelah, atau

memenangkan/memprioritaskan

kepentingan satu golongan, apalagi satu orang saja, di atas kepentingan golongan yang lain. Prinsip bahwa keputusan yang diambil secara aklamasi merupakan keputusan yang paling ideal. Prinsip bahwa manakala kesimpulan yang dicapai setelah dilaksanakan musyawarah secara

18 Ibid, hlm, 16 bijaksana (free and fair) dengan memberikan kesempatan mendengarkan pendapat yang cukup luas dan memberikan kesempatan bicara kepada semua pihak yang berkepentingan, maka keputusan yang diambil wajib mencerminkan hasil permusyawaratan ${ }^{19}$.

3. Musyawarah dan mufakat

Musayawarah Mufakat pada dasarnya adalah usaha untuk mencari hakekat kebenaran, keadilan, kesempurnaan tertinggi dan terbaik dalam proses pengambilan keputusan melalui suatu mekanisme yang damai dengan mengedepankan etika yang sesuai dengan kelaziman dan kepatutan. Kelaziman dan kepatutan yang dimaksud adalah yang sesuai dengan agama, etika dan moral yang menjadi tradisi yang hidup dan berkembang dalam masyarakat Indonesia. Kondisi aman damai dalam proses pengambilan keputusan akan berimplikasi pada pelaksanaan hasil kesepakatan dengan lancar sehingga

19 Sunaryati Hartono. mencari makna nilai-nilai falsafah dl dalam pancasila sebagai weltanschauung bangsa dan negara republik indonesia* Disampaikan dalam Forum Dialog Nasional Bidang Hukum dan Non Hukum yang diselenggarakan oleh Badan Pembinaan Hukum Nasional . Kementenan Hukum dan Hak Asasi Manusia Rl pada tanggal 5-7 Oktober 2011 di Hotel Bidakara Jakarta. MENCARI MAKNA NILAI-NILAI FALSAFAH D1 DALAM PANCASILA ... perpustakaan.bphn.go.id. diunduh pada hari sabtu 8 oktober 2016.

Herlambang, Perwujudan Sila Ke Empat Pancasila Setelah Perubahan Undang-Undang Dasar 1945 
mempermudah untuk terwujudnya tujuan bersama ${ }^{20}$.

Keputusan yang diambil secara musyawarah itu wajib dihormati/disetujui dan dilaksanakan, berdasarkan itikad baik sesuai dengan semangat dan pemahaman pengambilan keputusan, pada saat pengambilan keputusan yang bersangkutan. ${ }^{21}$

Permusyawaratan seharusnya menjadi dasar pengambil keputusan bagi seluruh pengambil keputusan di Republik Indonesia baik bagi pembuat undang-undang maupun pemerintah dan Hakim Pengadilan serta komponenn masyarakat lainya (Pers, LSM,Ornop d11). Dalam hal ini nilainilai Pancasila yang perlu dipakai untuk menentukan batas-batas antara kepatuhan pada hukum (kepastian hukum) dan nilai-nilai kebebasan individu serta antara perilaku sosial yang masih dapat ditoler, sesuai dengan nilai-nilai kepatuhan dan keadilan bagi orang/masyarakat yang beradab. ${ }^{22}$ Saat ini kecendrungan pengadopsian nilai-nilai demokrasi liberal melunturkan nilai-nilai tradisi

20 Ibid

21 Ibid

22 Ibid yang seharusnya tetap dilestarikan dalam kehidupan berbangsa dan bernegara. Prinsip Demokrasi Liberal berbeda dengan prinsip Demokrasi Pancasila. Prinsip Demokrasi Liberal sebagaimana dikemukakan oleh Immanuel Kant, yang bertumpu atas "liberty"(vrijheid) yang merupakan suatu kondisi yang memungkinkan pelaksanaan secara bebas dan hanya dibatasi seperlunya untuk menjamin koeksistensi yang harmonis antara kehendak bebas individu dengan kehendak yang lain. Dari sinilah mengalir prinsip selanjutnya yaitu, "freedom from arbitrary and unreasonable exercise of the poer and autority". Sedangkan konsep equality mengandung makna yang abstrak dan formal (abtrak -formal) ${ }^{23}$

Demokrasi Pancasila yang sangat mengedepankan nilai-nilai dan etika moral sebagaimana teraktualisasi dalam idiologi negara Pancasila. Tradisi musyawarah dan mufakat yang menjadi karakteristik

23 Siti Hasanah. Penguatan Tradisi Musyawara Mufakat dalam Sistem Kekuasaan Negara:Studi $T$ entang Lembaga MPR di Masa Kini dan kan datang. https://publikasiilmiah.ums.ac.id. Diunduh pada hari sabtu tanggal 8 oktober 2016. Pukul 13.50

Herlambang, Perwujudan Sila Ke Empat Pancasila Setelah Perubahan Undang-Undang Dasar 1945 
atau ciri demokrasi Indonesia dijadikan sebagai pilar utama oleh para pendiri bangsa yang diangkat

kedalam format pelaksanaan fungsi dan tugas kenegaraan. ${ }^{24}$ Tradisi ini menjadi seharusnya menjadi sendi utama dalam pengambilan kebijakan dan keputusan dalam lembaga MPR yang merupakan lembaga permusyawaratan Rakyat. 25

Di Indonesia tradisi musyawarah mufakat yang berasal dari norma kebiasaan yang berlaku dalam bentuk yang sederhana pada komunitas desa yang kecil dan terbatas, diangkat menjadi suatu gagasan bangsa setelah terbentuk negara Indonesia. Tradisi tersebut disesuaikan dengan struktur negara modern dan diperluas pada wilayah negara yang lebih besar dengan mempertahankan prinsip-prinsip pokoknya sebagaimana teraktualisasi dalam pancasila dan UUD 1945 yang menjadi ideologi dan konstitusi negara Indonesia. 26

Saat ini Musyawarah dan mufakat yang seharusnya menjadi sendi utama dalam pengambilan keputusan dalam lembaga MPR menjadi berubah bukan musyawarah

24 Ibid

25 Ibid

26 Ibid untuk mencapai mufakat akan tetapi system voting dengan prinsip one man

one vote yang lebih mengedepankan hak individu yang berbeda dengan esensi dasar musyawarah mufakat dan kebersamaan.

Esensi dasar yang terdapat dalam musyawarah dan mufakat adalah mencari hakekat kebenaran, keadilan, kesempurnaan tertinggi dan terbaik dalam proses pengambilan keputusan melalui suatu mekanisme yang damai dengan mengedepankan etika yang sesuai dengan kelaziman dan kepatutan. Kelaziman dan kepatutan yang dimaksud adalah yang sesuai dengan agama, etika dan moral yang menjadi tradisi yang hidup dan berkembang dalam masyarakat Indonesia. Kondisi aman damai dalam proses pengambilan keputusan akan berimplikasi pada pelaksanaan hasil kesepakatan dengan lancar sehingga mempermudah untuk terwujudnya tujuan bersama. ${ }^{27}$

Amandemen UUD 1945 merupakan langkah positif kearah kemajuan, yang berupaya untuk mengembalikan esensi mendasar dalam Demokrasi Pancasila yang selama beberapa puluh tahun

27 Ibid

Herlambang, Perwujudan Sila Ke Empat Pancasila Setelah Perubahan Undang-Undang Dasar 1945 
terkoptasi dalam belenggu penguasa. Nilai dasar demokrasi sebagai suatu pikiran menutut terjadinya kemerdekaan dan keadilan bagi setiap orang dalam kehidupan bermasyarakat dan bernegara, yang konsekwensinya perlu diusahakan dan dipeliharanya beberapa macam keseimbangan yaitu:

a. Keseimbangan individu dan masyarakat

b. Keseimbangan diantara dimensi hidup physik dan dimensi hidup kerohanian yang permanen dari pada manusi

c. Keseimbangan antara nilai-nilai integratif dan nilai desintegratif

d. Keseimbangan antara tujuan dan untuk mencapai tujuan

e. Keseimbangan antara kemerdekaan dan keadilan, yakni kemerdekaan yang menjamin keadilan dan keadilan yang menjamin kemerdekaan. ${ }^{28}$

Tradisi musyawarah warga yang dilandasi dengan hubungan sosial intensif, kooperatif, interaktif dengan asas timbal-balik (resiprositas), saling percaya dan kerelaan berbagi yang merupakan modal sosial-kultural yang sanggup membentengi dari kekacauan sosial dengan relasi yang ko-eksistensi

28 Fahrul Muzaqqi fahrul. Musyawarah Mufakat: Gagasan dan Tradisi Genial Demokrasi Deliberatif di Indonesia Media Jurnal Politik Indonesia. Volume : 1 - No. 2 Terbit : 10-2012. Diunduh pada Hari Minggu tanggal 9 ktober 2016 pukul 14.04

Herlambang, Perwujudan Sila Ke Empat Pancasila Setelah Perubahan Undang-Undang Dasar 1945

(saling menghormati) dan proeksistensi (saling Menghidupi) ${ }^{29}$.

4. Lembaga perwakilan

Dari aspek jumlah penduduk, Indonesia yang memiliki jumlah penduduk yang sangat banyak terdiri dari berjuta-juta jiwa tidak mungkin untuk dikumpulkan disuatu waktu dan tempat tertentu untuk ikut serta secara langsung menentukan kebijakan pemerintahan, sehingga dibutuhkan orang-orang tertentu yang bisa mewakili kepentingan mereka dalam proses tersebut. 30

Keanggotaan MPR dipilih oleh rakyat melalui mekanisme pemilihan umum yang di Indonesia disebut pemilu legislatif. Di era orde lama dan orde Baru pemilihan umum hanya dilakukan sekali dalam 5 (lima) tahun dan tidak ada pembedaan antara pemilu legislatif dan pemilu presiden. Sejak bergulirnya Era Reformasi maka sistem pemilu di Indonesia mengalami perubahan mendasar. Pemilu legislatif dan pemilu presiden di laksanakan secara terpisah. Pemilu legislatisf dilaksanakan terlebih dahulu. Setelah adanya penetapan hasil pemilu legislatif maka tiap partai politik yang memenuhi syarat berdasarkan

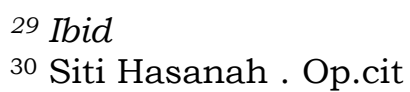

30 Siti Hasanah . Op.cit 
ketentuan perundangan-undangan mengajukan calon presiden dan wakil Presiden. Tahapan selanjutnya dilakukan pemilihan presiden dan wakil presiden yang dilakukan secara langsug oleh rakyat. Situasi inilah yang sangat mempengaruhi peran dan fungsi MPR sebagai lembaga yang dulu di Era Orde Baru memiliki otoritas yang sangat kuat karena lembaga inilah yang memiliki kewenangan untuk memilih Presiden dan Wakil Presiden. Sejak terjadinya perubahan sistem pemilu pasca amandemen UUD 1945 maka Esensi dasar nilai musyawarah dan mufakat yang teraktualisasi dalam mekanisme pengambilan kebijakan dan keputusan pemerintahan di lembaga MPR khususnya berkaitan dengan pemilihan presiden dan Wakil Presiden menjadi hilang. ${ }^{31}$

$$
\text { MPR saharusnya berfungsi }
$$
sebagai rumah atau tempat berkumpulnya para wakil rakyat yang akan mewakili rakyat dalam beberapa segmen dan wilayah. Lembaga ini merupakan corong aspirasi dan pengemban amanat dan kehendak rakyat sehingga dalam menjalankan fungsi dan tugasnya tidak boleh

31 ibid bertolak belakang dengan aspirasi atau kehendak yang diwakilinya. ${ }^{32}$

$$
\text { Fungsi }
$$

Majelis

Permusyawaratan Rakyat Indonesia sering kali direduksi sebagai ogan yang melaksanakan fungsi legislasi semata-mata.

Seringkali dipahami bahwa fungsi legislasi hanya terkait dengan fungsi pembuatan undang-undang dalam pengertian yang sempit. Karena itu, yang biasa dipahami sebagai lembaga legislatif berdasarkan UUD 1945 pasca reformasi hanya DPR dan DPD saja. Bahkan, banyak pula tokoh-tokoh politik kita yang memahaminya lebih sempit lagi, yaitu bahwa lembaga yang mempunyai kewenangan langsung di bidang pembuatan undang-undang itu hanya DPR, sedangkan DPD hanya berfungsi sebagai 'advisory council' terhadap fungsi DPR. ${ }^{33}$

Pelembagaan fungsi legislature itulah yang disebut parlemen. Di berbagai negara ada yang melembagakannya dalam satu forum saja (unicameral atau monocameral), ada pula yang dua forum (bicamerah).

32 Ibid

33 Jimly Asshiddiqie. lembaga perwakilan dan permusyawaratan rakyat tingkat pusat. www.jimly.com/makalah/namafile/40/Tri kameralisme_DPD. Diunduh pada hari sabtu 8 Oktober 2016. Pukul 13.17 
Bahkan ada pula negara-negara yang mempunyai struktur parlemen multi kameral atau terdiri atas lebih dari dua kamar atau lebih dari dua institusi ${ }^{34}$. Salah satunya adalah Indonesia yang mempunyai tiga institusi atau tiga forum parlemen sekaligus, yaitu DPR, DPD, dan MPR. DPR merupakan lembaga perwakilan politik (political representation), DPR merupakan perwakilan daerah (regional representation), sedangkan MPR merupakan penjelmaan keseluruhan rakyat, baik dari segi politik maupun kedaerahan. ${ }^{35}$

C. Keberadaan MPR RI sebagai perwujudan Sila Ke empat.

(1) Majelis Permusyawaratan Rakyat terdiri atas anggota Dewan Perwakilan Rakyat dan anggota Dewan Perwakilan Daerah yang dipilih melalui pemilihan umum dan diatur lebih lanjut dengan undang-undang.

(2) Majelis Permusyawaratan Rakyat bersidang sedikitnya sekali dalam lima tahun di ibukota negara.

(3) Segala putusan Majelis Permusyawaratan Rakyat ditetapkan dengan suara yang terbanyak.

Sedangkan Pasal 3-nya menyatakan:

(1) Majelis Permusyawaratan Rakyat berwenang mengubah dan

34 Fatmawati, "Struktur dan Fungsi Legislasi Parlemen dengan Sistem Multikameral: Studi Perbandingan antara Indonesia dan Berbagai Negara", Disertasi Fakultas Hukum Universitas Indonesia, Jakarta, 2009.

35 Jimli Asshidiqi, Op.cit

Herlambang, Perwujudan Sila Ke Empat Pancasila Setelah Perubahan Undang-Undang Dasar 1945
(2) menetapkan undang-undang dasar.

(3) Majelis Permusyawaratan Rakyat melantik Presiden dan/atau Wakil Presiden.

(4) Majelis Permusyawaratan Rakyat hanya dapat memberhentikan Presiden dan/atau Wakil Presiden dalam masa jabatannya menurut undang-undang dasar.

Dapat dikatakan bahwa Pasal 2 UUD 1945 tersebut mengatur mengenai organ atau lembaganya, sedangkan Pasal 3 mengatur kewenangan lembaga MPR itu. Di samping itu, ada beberapa pasal lain dalam UUD 1945 yang juga mengatur tentang MPR, termasuk mengenai kewenangannya. Akan tetapi, pada bagian ini, yang dititik-beratkan hanya penegasan bahwa dalam UUD atau organ negara diatur secara eksplisit. ${ }^{36}$

Pengaturan kedudukan dan fungsi MPR di dalam UUD 1945 yang asli menegaskan bahwa kedaulatan rakyat Indonesia dijelmakan dalam tubuh MPR sebagai pelaku utama dan pelaksana sepenuhnya kedaulatan rakyat itu. Karena itu, bunyi rumusan asli Pasal 1 ayat (2) Bab I UUD 1945 adalah "Kedaulatan adalah di tangan rakyat dan dilakukan sepenuhnya oleh MPR”. Di samping itu, pada Bab III Pasal 6 ayat (2) ditentukan pula

36 Fatmawati, Op.Cit. 1945, status MPR itu sebagai lembaga 
bahwa "Presiden dan Wakil Presiden dipilih oleh Majelis Permusyawaratan Rakyat dengan suara yang terbanyak". ${ }^{37}$

$$
\text { Dalam UUD } 1945 \text { setelah }
$$

Perubahan Keempat, organ MPR juga tidak dapat lagi dipahami sebagai lembaga yang lebih tinggi kedudukannya daripada lembaga negara yang lain atau yang biasa dikenal dengan sebutan lembaga tertinggi negara. MPR sebagai lembaga negara sederajat levelnya dengan lembaga-lembaga negara yang lain seperti DPR, DPD, Presiden/Wakil Presiden, Mahkamah Konstitusi, Mahkamah Agung, dan Badan Pemeriksa Keuangan. Bahkan dalam hubungan dengan fungsinya, organ MPR dapat dikatakan bukanlah organ yang pekerjaannya bersifat rutin. Meskipun di atas kertas, MPR itu sebagai lembaga negara memang terus ada, tetapi dalam arti yang aktual atau nyata, organ MPR itu sendiri sebenarnya baru dapat dikatakan ada (actual existence) pada saat kewenangan atau 'functie'nya sedangkan dilaksanakan.

Kewenangannya itu adalah mengubah dan menetapkan undang-undang dasar (UUD), memberhentikan presiden dan/atau wakil presiden, memilih presiden atau wakil presiden untuk mengisi lowongan jabatan presiden atau wakil presiden, dan 'melantik' presiden dan/atau wakil presiden. 38

Sebagai perbandingan dapat diketengahkan dalam Konstitusi Amerika Serikat disebutkan bahwa "All legislative power vested in Congress which consist of the Senate and the House of Representatives". Segala kekuasaan legislatif berada di Kongres yang terdiri atas House of Representative dan Senat. Akan tetapi, dalam Pasal 2 ayat (1) UUD 1945 ketentuan mengenai MPR, dirumuskan secara berbeda, yaitu “MPR terdiri atas anggota DPR dan anggota DPD yang dipilih melalui pemilu dan diatur lebih lanjut dengan undang-undang". Dengan demikian, MPR tidak dikatakan terdiri atas DPR dan DPD, melainkan terdiri atas anggota DPR dan anggota DPD. Dengan demikian, MPR itu merupakan lembaga yang tidak terpisah dari institusi DPR dan DPD. ${ }^{39}$

\section{SIMPULAN}

Berdasarkan fakta dan kajian yang diungkapkan pada bagian terdahulu dapat disimpulkan beberapa hal, yaitu; 
1. Bahwa setelah Perubahan Undang Undang dasar 1945, maka keberadaan Majelis Permusyawaratan Rakyat tidak lagi menjadi representasi penjelmaan Sila keempat;

2. MPR bukan lagi sebagai lembaga tempat dilakukannya permusyawaratan Rakyat dalam menentukan arah kebijakan negara dan menentukan pemimpinnya.

3. MPR tidak lagi mnjadi lembaga yang mempresentasikan lahirnya keputusan yang dilakukan dengan Hikmah Kebijaksanaan

4. MPR bukan lagi menjadi tempat representasi perwakilan rakyat yang terdiri dari beberpa komponen (politisi, Tokoh Daerah, cerdik Cendikia, entrepreneur, tokoh agama, tokoh kebudayaan, dan lain komponen dala segmen masyarakat Indonesia) dan tidak lagi menjadi reperesentasi daerah dan kearifan lokal yang dimilikinya.

\section{DAFTAR PUSTAKA}

Ahmadnasher. Pancasila sebagai sistem Filsafat. ahmadnasher.staff.gunadarma.a c.id. diunduh pada hari selasa tanggal 12 April 2016. Pukul 12.40
Ali Taher Parasong. Internalisasi Pancasila dalam Pembentukan peraturan Perundang-undangan di Indonesia. http://fhumj.org diunduh pada hari selasa tanggal 12 April 2016 pukul 1634

Azyumardi Asra yang dikutip oleh Sadi Isra. Reaktualisasi Pancasila dalam Kehidupan Multikulturalisme. Semnar nasional "eksistensi Pancasila dalam era Pluralisme". BEM FH Univ, Atmadjaya. Yogyakarta. 2 Mei 2009.

Dani Pinasang . Falsafah Pancasila Sebagai Norma Dasar ((grundnorm) dalam rangka pengembanan sistem hukum nasional. Jurnal Unsrat Vol.XX/ No 3/Apri -juni/2012. http://repo.unsrat.ac.id.

Diunduh Pada Hari Jum'at tanggal 15 April 016 pukul $11 ; 14$.

Fatmawati, Struktur dan Fungsi Legislasi Parlemen dengan Sistem Multikameral: Studi Perbandingan antara Indonesia dan Berbagai Negara", disertasi Fakultas Hukum Universitas Indonesia, Jakarta, 2009.

Fahrul Muzaqqi fahrul. Musyawarah Mufakat: Gagasan dan Tradisi Genial Demokrasi Deliberatif di Indonesia Media Jurnal Politik Indonesia. Volume : 1 - No. 2 Terbit : 10-2012. Diunduh pada Hari Minggu tanggal 9 ktober 2016 pukul 14.04
Fatmawati, Struktur dan Fungsi Legislasi Parlemen dengan Sistem Multikameral: Studi Perbandingan antara Indonesia dan Berbagai Negara", Disertasi. 
Fakultas Hukum Universitas Indonesia, Jakarta, 2009.

Ginanjar Kartasasita. karakteristidka ns truktur masyarakat indonesia $\mathrm{m}$ odern. disampaikanp ada sarasehan u ji sahih a tas pokokpokok pikiran golkar tentang gbhn 1998. Jogyakarta 27 Juni 1997. H1m 14-15

Indri Djanarko. Pancasila sebagai sistem Filsafat. http://indridjanarko.dosen.narot ama.ac.id. Diunduh pada hari selasa 4 Oktober 2016 puul 12.15

Jimly Asshiddiqie. lembaga perwakilan dan permusyawaratan rakyat tingkat pusat.

www.jimly.com/makalah/namafi le/40/Trikameralisme_DPD.

Diunduh pada hari sabtu 8 Oktober 2016. Pukul 13.17

Nn. Teori Nilai. staff.uny.ac.id. diunduh Pada hari Rabu Tanggal 13 April 2016. Pukul. 14.22

Ongki Setio Kuncono.Poisi Pancasila sebagai landasan Hukum Di Indoesia.

http://www.spocjournal.com/ hukum. diunduh pada hari selasa tanggal 12 April 2016 pukul 16.19

Kaelan. Negara Kebangsaan Pancasila. Paradigma. Yogyakarta 2013Hlm 472.

perpustakaan.bphn.go.id. diunduh pada hari sabtu 8 oktober 2016.
Roeslan Abdul Gani, yang dikutip oleh Heri Santoso dkk.Uj koherensi dan korespodensi. Aktualisasi nilai- nilai pancasila dalam produk undang-undang, Pasca Reformasi (Tinjauan Filosofis, sosiologis dan Yuridis.. Prosiding Kongres Pancasila IV: Srategi Pelembagaan Nilai-Nilai Pncasila. https://books.google.co.id

Rowland Bismark Fernando Pasaribu. Pancasila sebagi sistem Filsafat. staff.gunadarma.ac.id. diunduh pada hari Jum'at tanggal 15 April 2016 pukul 11.01

Siti Hasanah. Penguatan Tradisi Musyawara Mufakat dalam Sistem Kekuasaan Negara:Studi T entang Lembaga MPR di Masa Kini dan kan datang. https: / / publikasiilmiah.ums.ac.i d. Diunduh pada hari sabtu tanggal 8 oktober 2016. Pukul 13.50

Sri Edi Swasono. Pancasila dan Tanggungjawab Intlektual kita. Seminar nasional Strategi Pembudayaan nilai nilai Pancasila.dalam menguatkan semangat keindonesiaan. Prosiding Kongres Pancasila Ke V Tahun 2013

Sri Widayati. Arti Pancasila Sebagai Sumber Hukum. http://www.gexcess.com. Diunduh pada Hari selasa tanggal 12 april 2016 pukul 16.21

Sunaryati Hartono. mencari makna nilai-nilai falsafah dl dalam pancasila sebagai weltanschauung bangsa dan negara republik indonesia* Disampaikan dalam Forum Dialog Nasional Bidang Hukum dan Non Hukum yang diselenggarakan oleh Badan Pembinaan Hukum Nasional

Herlambang, Perwujudan Sila Ke Empat Pancasila Setelah Perubahan Undang-Undang Dasar 1945 
Supremasi Hukum : Jurnal Penelitian Hukum

p-ISSN: 1693-766X ; e-ISSN: 2579-4663, Vol. 26, No. 2, Agustus 2017

Yudi Latif, Negara Paripurna:

Historisitas, Rasionalitas, dan

Aktualitas Pancasila, Jakarta:

Kompas Gramedia, 2011, hlm.

67.

Herlambang, Perwujudan Sila Ke Empat Pancasila Setelah Perubahan Undang-Undang Dasar 1945 